\title{
POSSIBLE TECHNIQUES FOR TRANSLATING PERSONAL NAMES IN CHILDREN AND YOUNG ADULT LITERATURE
}

\author{
Ani Susanti \\ Universitas Ahmad Dahlan, Yogyakarta
}

\section{A. Effendi Kadarisman}

Universitas Negeri Malang

\begin{abstract}
Personal names are considered "specific words"and thus most often kept untranslated. However, as translation theory has developed, making it not only changing language features but also mediating cultural aspects, personal names are reconsidered in translation. Since they are culturally bound, this study aims to find out, when personal names are translated, what translation strategies apply and why. The data were collected from the weekly comic Donal Bebek (2018) as well as from the Hunger Games trilogy novels written by Suzanne Collins $(2008,2009,2010)$ and translated by Hetih Rusli $(2009,2010,2012)$. The findings show that translating personal names in children literature can be more complicated than translating thosein literature for older readers. This study has found out that four strategies (preservation, naturalization, couplet, and adaptation) are used to approach the personal names translation for the children literature; and only two strategies (preservation and literal translation) are applied to the translation of those in young adult literature. Reasons for using such strategies are as follows: several aspects (such as connotation, pronunciation, and style) have been considered when translating personal names in children literature, while they are more flexible when translating personal names in young adult literature.
\end{abstract}

Keywords: translating personal names, translation techniques, children literature, young adult literature

\begin{abstract}
Abstrak: Nama diri merupakan 'kata yang khas' dan karena itu seringkali tidak diterjemahkan. Namun, karena teori terjemahan telah berkembang, dimana menerjemahkan berarti tidak hanya mengubah fitur bahasa tetapi juga memediasi aspek budaya, nama diri dipertimbangkan ulang dalam penerjemahan. Karena namanama diri terikat secara budaya, penelitian ini bertujuan mengetahui kapan namadiri diterjemahkan, strategi apa yang digunakan, dan apa alasannya. Sumber data dikumpulkan dari komik mingguan Donal Bebek (2018) serta dari novel trilogi Hunger Games yang ditulis oleh Suzanne Collins (2008, 2009, 2010) dan diterjemahkan oleh Hetih Rusli (2009, 2010, 2012). Hasil penelitian ini menunjukkan bahwa menerjemahkan nama-nama diri dalam sastra anak-anak bisa
\end{abstract}


lebih rumit daripada menerjemahkannya nama-nama diri dalam sastra untuk pembaca remaja. Penelitian ini telah mencatat bahwa empat strategi (pelestarian, naturalisasi, kuplet dan adaptasi) digunakan untuk menerjemahkan nama diri untuk sastra anak-anak; dan hanya dua strategi (pelestarian dan terjemahan literal) diterapkan untuk penerjemahan nama diri dalam sastra remaja. Ada sejumlah alas an untuk menggunakan strategi-strategi tersebut: aspek-aspek lingualseperti konotasi, pengucapan, dan gayabahasaperlu dipertimbangkan saat menerjemahkan namanama diri dalam sastra anak-anak, sedangkan proses menerjemahkan nama-nama diri dalam sastra remaja cenderung lebih lentur.

Key words: penerjemahan nama diri, teknik-teknik penerjemahan, sastra anak-anak, sastra remaja

\section{INTRODUCTION}

Most people who have limited translation experience might consider that personal names should not be translated. However, the literature and translation practices have shown that names can be either preserved or translated. Zarei and Norouzi (2014) write that before the seventies, proper nouns were considered a grammatical category that should be translated, but since then there is a tendency to leave them untranslated. This was a shifting paradigm in translation theory. Al-Hassan and Jordan (2013) explain that in the initial phase of translation theory, translation was known as replacing a text in one language to another in the target language with the main emphasis on linguistic aspects, but in the later phase, translation studies have expanded to include cultural aspects; so more recently a translator is not only a language mediator but also a cultural mediator (Al-Hassan and Jordan, 2013). While it may be true that proper nouns need no translation, there are some exceptions regarding the translation of personal names.

Along this line of reasoning, when personal names are translated within the process of rendering the source language text into the target language text, this study aims to find out, first, what translation strategies apply, and secondly, why such strategies are selected.

\section{PERSONAL NAMES TRANSLATION}

Newmark (1988: 214) writes that names (first names and surnames) are usually transferred directly, especially when the nationality is important and the names have no relevant connotations. He adds that there is an exception for the names of famous saints, monarchs, popes, and prominent classical figures (Newmark, 1988: 214). That is why in Indonesian, Alexander the Great is translated as IskandarAgung, Pope Francis is translated as PausFransiskus, and Avicenna is translated as IbnuSina. I believe this exception is quite reasonable, because such figures have had influential roles due respectively to his ancient political leadership, his world-wide religious dominance, and his strong influence in philosophical and scientific ideas; therefore their names should be adjusted so that people from different language backgrounds find them easier to engage with.

Besides the aforementioned personal names, Newmark (1988: 215) explains further that names which have relevant connotations in imaginative literature are also translated, for example, Harriet, the name of a chicken in P.G. Wodehouse's Love among the Chickens, is rendered as Laura in Swedish to maintain the incongruous connotation of the name. In line with this idea, Aguilera (2008) believes that proper nouns can also be 
translated and substituted, particularly when dealing with children literature. Children are classified into three levels (pre-reading, age $0-6$ years old; reading and writing, age 6 to adolescents; and adolescents and older); the lower their age, the lower the capability of understanding and accepting foreign words (Aguilera, 2008). This means that the translation of children's literature targeting the lower level should be more sensitive. This is relevant to the translation of personal names in fairy tales and cartoons. For instance, Cinderella is translated as Cenerentola in Italian, Cendrillon in German, and Ashenputtelin German; and Snow White is translated as Schneewittchen in German and PutriSalju in Indonesian.

Translators do not use the same strategy for translating names in all texts (Pour, 2009). However, several studies have reported common strategies on how translators approach personal names. Jaleniauskienė and Čičelytė (2009) report that the most frequently used strategies in translating personal names in children literature are preservation, transformation, and creation, as well as localization. While, Abdolmaleki (2012) suggests four possible ways of translating proper nouns in general texts: (1) keep them unchanged from the original version; Newmark (1988: 81) labels this strategy as transference; (2) modify them at the level of spelling and phonology; Newmark (1988: 81) calls this strategy naturalization; (3) expand them in order to provide meaningful information in the target culture; and (4) eliminate them if the names cause confusion for the readers in the target culture.

There are no prescribed rules on how personal names should be translated, but the above-mentioned studies indicate that readers in the target language are among key factors influencing the translators' decisions. To see the difference how translators approach personal names in texts with different target readers, the next sections of this paper discus the translation of personal names in children and young adult literature from English into Indonesian.

\section{RESEARCH METHODS}

The personal names are collected from two main sources; Donal Bebek comics and Hunger Games trilogy novels. The first data source is from weekly comic Donal Bebek $\left(1906^{\text {th }}\right.$ and $1907^{\text {th }}$ editions, 2018) published by PT PenerbitanSaranaBobo under the licence from The Walt Disney Co. This comic tells stories about Donald Duck and other cartoon characters from world famous Walt Disney. This comic, a pioneer of picture stories in Indonesia, is mostly suitable for children in pre-reading level and young adolescents. The researchers first list the names, then find out the English names using clues from open source (www.wikipedia.com) and then match the clues with names itemized in Walt Disney character directory (www.characters.disney.com and animation source website (www.animationsource.org). The researchers then identify the translation techniques and make interpretations about the translator decisions for selecting the technique.

Next, the second data source is from Hunger Games novels written by Suzanne Collins (2008, 2009, 2010) originally in English and the Indonesian version translated by HetihRusli (2009, 2010, 2012). These novels include The Hunger Games (2008), Catching Fire (2009), Mockingjay (2010) published by Scholastic Press and the translated version published by GramediaPustakaUtama. These trilogy novels, best for young adults, tell about unspecified future of North America that changes into a country named Panem, 
consisting of a wealthy Capitol and 12 poor districts. Every year a young couple from each district should join a televised pageant involving death match supported by advanced technology called Hunger Games. The winning couple and their home district will be compensated for with food and other supplies. The researchers list names from the English versions and find out those translated names in the Indonesian versions.

\section{FINDINGS AND DISCUSSION}

This section consists of two sub-sections: translation of personal names in Donal Bebek comics and translation of personal names in the trilogy novels Hunger Games.

\section{Personal Names Translation in Donal Bebek Comics}

Twelve names appeared in the two editions of Donal Bebek as shown in Table 1.

Table1. Personal Names in Donal Bebek Comics

\begin{tabular}{ccc}
\hline No & Indonesian Names & English Names \\
\hline 1. & Lady & Lady \\
\hline 2. & Silky & Silky \\
\hline 3. & Gufi & Goofy \\
\hline 4. & Donal Bebek & Donald Duck \\
\hline 5. & DesiBebek & Daisy Duck \\
\hline 6. & Miki Tikus & Mickey Mouse \\
\hline 7. & AgusAngsa & Gus Goose \\
\hline 8. & Midas Serigala & Big Bad Wolf \\
\hline 9. & Lang Ling Lung & Gyro Gearloose \\
\hline 10. & PamanGober & Scrooge McDuck \\
\hline 11. & Kwik, Kwek, Kwak & Huey, Duey, Louie \\
\hline 12. & Berandal & Scamp \\
\hline
\end{tabular}

There are four translation techniques used for these twelve character names: (a) Pure Transference / Preservation: Lady and Silky, names of dogs, are preserved. There are two reasons why these names are purely transferred. First, Indonesian children possibly will not have difficulties in pronouncing the names. Second, as synthesized by Jaleniauskienè and Čičelyte (2009), names that include descriptive elements are not translated. The word 'lady' characterizes a woman of higher social status; in this case, 'Lady' is a name of a female cocker spaniel that lives in an upper-class family. Then, the word 'silky' is an adjective to resemble silk which is soft or smooth. Thus 'Silky' in the story refers to a dog whose character is soft and polite. (b) Naturalisation: Goofy is naturalized into Gufi.The phonetic transcription of Goofy is /gu:fi/ and thus it will be easier for Indonesian children if the spelling of the name is closer to how it is pronounced. (c) Couplet: Couplet is combining two techniques in translating a single word or phrase (Newmark, 1988: 91). (i) Naturalization + Literal Translation: There are three names (Donal Bebek, DesiBebek, and Miki Tikus) which are translated using the combination of naturalization and literal 
$62 \mid$ Bahasa dan Seni: Jurnal Bahasa, Sastra, Seni, dan Pengajarannya

Volume 47, Nomor 1, Februari 2019

translation. The second names 'Duck' and 'Mouse,' indicating species, are translated literally as Bebek and Tikus.But first names Donald, Daisy, and Mickey are translated closer to their phonetic transcription; Donald /dpnəld/ becomes Donal, Daisy /dæsi/ becomes Desi, and Mickey /miki/ becomes Miki. (ii) Substitution (Localization) + Literal Translation: The other couplet technique is the combination of substitution and literal translation as it is found in Gus Goose which is creatively translated as AgusAngsa. The second name Goose is literally translated as Angsa. While the first name Gus is substituted with Agus which is a typically Indonesian name. The substitution reason is that Gus has a specific connotation in Indonesian context; Gus refers to a son of a Muslim scholar, for example, Gus Dur (fourth Indonesian president) is the son of Muslim scholar K. H. Wahid Hasyim. Therefore, to make it unbiased, the translator chooses Agus to substitute Gus which sounds similar. Also, Agus $\underline{A}$ gsa has more stylistic assonance; it could still maintain the original stylistic alliteration of Gus Goose. (d) Substitution and Adaptation: The translator has used the substitution and adaptation technique for these following names based on several reasons as shown in table 2 .

Table 2. Substitution and Adaptation Technique and its Reasons

\begin{tabular}{|c|c|c|}
\hline No & $\begin{array}{l}\text { American names (A) } \\
\text { and } \\
\text { Indonesian names (I) }\end{array}$ & Explanation \\
\hline 1. & $\begin{array}{l}\text { Big Bad Wolf (A) } \\
\text { Midas Serigala (I) }\end{array}$ & $\begin{array}{l}\text { The last name Wolf is literally translated as } \\
\text { Serigala. The substitution Midas is taken from } \\
\text { the middle name of his alias name, Zeke Midas } \\
\text { Wolf. }\end{array}$ \\
\hline 2. & $\begin{array}{l}\text { Gyro Gearloose(A) } \\
\text { Lang Ling Lung (I) }\end{array}$ & $\begin{array}{l}\text { Gyro Gearloose is a famous inventor in the } \\
\text { Donald Duck universe, but his ideas are often } \\
\text { outrageous. He is such a 'linglung' person. } \\
\text { Linglung in Indonesian describes an absent- } \\
\text { minded person because s/he is confused or too } \\
\text { serious in thinking of an object. Then, to make } \\
\text { the Indonesian name more stylistic, the translator } \\
\text { creatively modified the name into Lang Ling } \\
\text { Lung. }\end{array}$ \\
\hline 3. & $\begin{array}{l}\text { Scrooge } \operatorname{McDuck}(\mathrm{A}) \\
\text { PamanGober }(\mathrm{I})\end{array}$ & $\begin{array}{l}\text { Scrooge McDuck is also popular as Uncle } \\
\text { Scrooge. Thus the translator uses 'Paman'as a } \\
\text { literal translation of 'uncle.' While Gober is } \\
\text { simplified from the Dutch name of Scrooge } \\
\text { McDuck, Dagobert Duck. The translator chooses } \\
\text { to adapt from Dutch name because the English } \\
\text { name Scrooge /skru:d3/ is more difficult for } \\
\text { children to pronounce. Denham and Lobeck } \\
\text { (2013: 124) write that the structure of children's }\end{array}$ \\
\hline
\end{tabular}




\begin{tabular}{|c|c|c|}
\hline No & $\begin{array}{l}\text { American names (A) } \\
\text { and } \\
\text { Indonesian names (I) }\end{array}$ & Explanation \\
\hline & & $\begin{array}{l}\text { syllables is Consonant - Vocal (CV). Notice that } \\
\text { Gober consists of two syllables: 'Go-' CV and } \\
\text { '-ber' CVC, which sounds more common and } \\
\text { natural in Indonesian than a single syllable } \\
\text { Scrooge: CCCVVCC. }\end{array}$ \\
\hline 4. & $\begin{array}{l}\text { Huey, Duey, Louie(A) } \\
\text { Kwik, Kwek, Kwak (I) }\end{array}$ & $\begin{array}{l}\text { The American names of these triplet little ducks } \\
\text { (/hui/, /dui/ and /lui/) possibly sound strange and } \\
\text { uncommon as Indonesian names. Therefore they } \\
\text { are modified following the sound of duck } \\
\text { 'quack-quack', whose onomatopoeic Indonesian } \\
\text { equivalent is 'kwek-kwek'. For the stylistic } \\
\text { reason, the triplet names then become Kwik, } \\
\text { Kwek, and Kwak. }\end{array}$ \\
\hline 5. & $\begin{array}{l}\text { Scamp (A) } \\
\text { Berandal (I) }\end{array}$ & $\begin{array}{l}\text { The personalities of Scamp in the stories are } \\
\text { stubborn and disobedient. A person with this } \\
\text { personality is frequently called berandal in the } \\
\text { Indonesian context. The translated name } \\
\text { 'Berandal' is taken from the personalities of the } \\
\text { character. }\end{array}$ \\
\hline
\end{tabular}

\section{Personal Names Translation in Young Adult Literature}

Most personal names in Hunger Games are preserved in the translation, except a few, which are given literal translation. Alphabetically, these names are listed in Table 3.

Table 3. Personal Names in Hunger Games and their Indonesian Translations

\begin{tabular}{|c|c|c|c|c|c|}
\hline No & English & Indonesian & No & English & Indonesian \\
\hline 1. & Annie Cresta & Annie Cresta & 45. & Leeg 1 & Leeg 1 \\
\hline 2. & Atala & Atala & 46. & Leeg 2 & Leeg 2 \\
\hline 3. & Beetee (Volts) & Beetee (Volts) & 47. & Leevy & Leevy \\
\hline 4. & Blight & Blight & 48. & Lyme & Lyme \\
\hline 5. & Boggs & Boggs & 49. & Madge Undersee & Madge Undersee \\
\hline 6. & Bonnie & Bonnie & 50. & Mags & Mags \\
\hline 7. & Bristel & Bristel & 51. & Martin & Martin \\
\hline 8. & Brutus & Brutus & 52. & Marvel & Marvel \\
\hline 9. & Buttercup & Buttercup & 53. & Mayor Undersee & Wali Kota Undersee \\
\hline 10. & Caesar Flickerman & Caesar Flickerman & 54. & Maysilee Donner & Maysilee Donner \\
\hline 11. & Cashmere & Cashmere & 55. & Messalla & Messalla \\
\hline 12. & Castor & Castor & 56. & Mitchell & Mitchell \\
\hline 13. & Cato & Cato & 57. & Morphlings & Morphlings \\
\hline 14. & Cecelia & Cecelia & 58. & Mr. Everdeen & Mr. Everdeen \\
\hline 15. & Chaff & Chaff & 59. & Mr. Mellark & Mr. Mellark \\
\hline 16. & Cinna & Cinna & 60 & Octavia & Octavia \\
\hline
\end{tabular}


64 | Bahasa dan Seni: Jurnal Bahasa, Sastra, Seni, dan Pengajarannya Volume 47, Nomor 1, Februari 2019

\begin{tabular}{|c|c|c|c|c|c|}
\hline 17. & $\begin{array}{l}\text { Claudius } \\
\text { Templesmith }\end{array}$ & $\begin{array}{l}\text { Claudius } \\
\text { Templesmith }\end{array}$ & 61. & PeetaMellark & PeetaMellark \\
\hline 18. & Clove & Clove & 62. & $\begin{array}{l}\text { Plutarch } \\
\text { Heavensbee }\end{array}$ & Plutarch Heavensbee \\
\hline 19. & Cray & Cray & 63. & Pollux & Pollux \\
\hline 20. & Cressida & Cressida & 64. & Portia & Portia \\
\hline 21. & Dalton & Dalton & 65. & Posy Hawthorne & Posy Hawthorne \\
\hline 22. & Darius & Darius & 66. & President Coin & Presiden Coin \\
\hline 23. & Delly Cartwright & Delly Cartwright & 67. & President Snow & Presiden Snow \\
\hline 24. & Dr. Aurelius & Dr. Aurelius & 68. & Primrose Everdeen & Primrose Everdeen \\
\hline 25. & Eddy & Eddy & 69. & Purnia & Purnia \\
\hline 26. & Effie Trinket & Effie Trinket & 70. & $\begin{array}{l}\text { Commander } \\
\text { Paylor }\end{array}$ & KomandanPaylor \\
\hline 27. & Enobaria & Enobaria & 71. & Ripper & Ripper \\
\hline 28. & FinnickOdair & FinnickOdair & 72. & Romulus Thread & Romulus Thread \\
\hline 29. & Flavius & Flavius & 73. & Rooba & Rooba \\
\hline 30. & Foxface & Si MukaRubah & 74. & Rory Hawthorne & Rory Hawthorne \\
\hline 31. & FulviaCardew & FulviaCardew & 75. & Rue & Rue \\
\hline 32. & Gale Hawthorne & Gale Hawthorne & 76. & Seeder & Seeder \\
\hline 33. & Glimmer & Glimmer & 77. & Seneca Crane & Seneca Crane \\
\hline 34. & Gloss & Gloss & 78. & Tax & Tax \\
\hline 35. & The Goat Man & Pak Kambing & 79. & Thom & Thom \\
\hline 36. & Greasy Sae & Greasy Sae & 80. & Thresh & Thresh \\
\hline 37. & Haymitch Abernathy & $\begin{array}{l}\text { Haymitch } \\
\text { Abernathy }\end{array}$ & 81. & Tigris & Tigris \\
\hline 38. & Hazelle Hawthorne & Hazelle Hawthorne & 82. & Titus & Titus \\
\hline 39. & Homes & Homes & 83. & Twill & Twill \\
\hline 40. & Jackson & Jackson & 84. & Venia & Venia \\
\hline 41. & Johanna Mason & Johanna Mason & 85. & Vick Hawthorne & Vick Hawthorne \\
\hline 42. & KatnissEverdeen & KatnissEverdeen & 86. & Wiress (Nuts) & Wiress (Nuts) \\
\hline 43. & Lady & Lady & 87. & Woof & Woof \\
\hline 44. & Lavinia & Lavinia & & & \\
\hline
\end{tabular}

As can be seen in Table 3, the preservation technique is mostly chosen by HetihRusli (the translator) because she might consider that young adults are more open-minded than children in respecting foreign names. Aguilera (2008) states that the older the readers, the more capable they are in accepting foreign words, including foreign names. Moreover, the setting of the Hunger Games story is in North America, and it has been clearly stated by Newmark (1988: 124) that personal names are not translated when there is an emphasis of nationality.

However, it is interesting to note that the translator does translate several nicknames, especially the descriptive ones. Pour (2009) notes that nickname is shorter than the real name, for example, Sue as the nickname of Susan; besides, a nickname can also be descriptive, for example, The Iron Lady for Margaret Thatcher. Table 4 shows several cases of descriptive nicknames in Hunger Games which are given literal translation.

Table 4. Literal Translation of Nicknames in Hunger Games

\begin{tabular}{clc}
\hline NO & \multicolumn{1}{c}{ Source Language (English) } & \multicolumn{1}{c}{ Target Language (Indonesian) } \\
\hline \multirow{2}{*}{ 1. } & I don't know his real name, everyone & Akutaktahunamaaslinya, semua orang \\
& just calls him the Goat Man. & memanggilnyaPak Kambing.(I.p.298)
\end{tabular}


Susanti, Kadarisman, Possible Techniques for Translating | 65

\begin{tabular}{|c|c|c|}
\hline & (I.p.266) & \\
\hline \multirow{3}{*}{2.} & I try to work out who is left. Five & Akuberusahamengingatingatsiapasaja \\
\hline & Career Tributes. Foxface. Thresh & yang tersisa. Lima PesertaKarier. Si \\
\hline & and Rue. (I.p.156) & MukaRubah. Thresh dan Rue. (I.p.175-6). \\
\hline 3. & President Coin & Presiden Coin \\
\hline 4. & President Snow & Presiden Snow \\
\hline 5. & Commander Paylor & KomandanPaylor \\
\hline 6. & $\begin{array}{l}\text { The Head Peacekeeper loved wild } \\
\text { turkey. (I.p.52) }\end{array}$ & $\begin{array}{l}\text { PemimpinPenjagaPerdamaiansukakalkun } \\
\text { liar. (I.p.62) }\end{array}$ \\
\hline 7. & $\begin{array}{l}\text { "Go on, then, Lover Boy," says the } \\
\text { boy from District 2. (I.p.160) }\end{array}$ & $\begin{array}{l}\text { "Pergisana, Lover Boy," kata } \\
\text { anaklelakidariDistrik 2. (I.p.180) }\end{array}$ \\
\hline 8. & $\begin{array}{l}\text { "Johanna's nicknamed them Nuts } \\
\text { and Volts," he says. "I think she's } \\
\text { Nuts and he's Volts." II.p.191. }\end{array}$ & $\begin{array}{l}\text { “Johanna menjulukimerekaNuts dan } \\
\text { Volts," kata Peeta. "Kurasa yang } \\
\text { perempuanNuts danlelakinyaVolts" } \\
\text { II.p. } 249\end{array}$ \\
\hline
\end{tabular}

As shown in Table 4, the translator used the literal translation technique for the title (president/presiden and commander/komandan) as shown in (3), (4), and (5). She also used a similar technique for translating nicknames in (1) Goat Man/Pak Kambing and (6) The Head Peacekeeper/PimpinanPenjagaPerdamaian, and also used the same technique with the addition of 'Si' for the nickname in (2) Foxface/Si MukaRubah. 'Si' is one of the Indonesian articles that is attached to someone's name and adjective (Simanjuntak, 2014).

Different from those in (1), (2), and (6), the nickname in (7) is unique because Lover Boy is kept as it is, using the preservation technique. 'Lover Boy' belongs to English slang, referring to a lover or an attractive man that makes girls easily fall in love (Heriyati, 2010). Slang is part of language variation, socially popular among youngsters, and sometimes gives prestige to the speakers (Zhou and Fan, 2013; Muhartoyo and Wijaya, 2014). In this respect, the translator keeps using 'Lover Boy' because she probably assumes that the readers are familiar with the meaning of this expression. It is also possible that she intentionally introduces the slang expression to attract readers who have not known yet about the meaning.

Finally, the nicknames Nuts and Volts in number (8), like number (7), are also preserved in the translation: Nuts dan Volts. Notice that the preservation here is probably motivated by the 'suggestive meaning' of each word. The word Nuts (in machinery) applies to the female; and Volts (in physics) applies to the male. This semantic play is much like sound symbolism in phonology, where sounds may suggest meaning, such as the word knock, which refers to the 'act of knocking'.

\section{CONCLUSION}

Personal names translation could be problematic because names are culturally and contextually bond. Referring particularly to translating literary works, the adjustment should consider acceptance degree by the target readers in responding to foreign names. When the target readers are children, the translation of personal names should be more 
66 | Bahasa dan Seni: Jurnal Bahasa, Sastra, Seni, dan Pengajarannya

Volume 47, Nomor 1, Februari 2019

careful, considering several aspects such as pronunciation, connotation, and style. But the translation of texts for young adult readers can be more flexible in terms of preserving the original foreign names and translating descriptive nicknames. Moreover, a translator, as a cultural mediator, can introduce some slang to the readers. Above all, translators should understand how personal names are commonly translated. Small samples discussion in this paper has shown several practices of personal names translation in children and adult literature by experienced translators using techniques of preservation, naturalization, couplet, substitution, adaptation, and literal translation. Further studies should explore translation of personal names, which include names of places and objects, especially in adult literature and in other genres or text types, both from English and any other language into Indonesian.

\section{REFERENCES:}

Abdolmaleki, S.D. 2012. Proper Names in Translation: an Explanatory Attempt. The Social Sciences, 7(6), 832-837.

Al-Hassan, A., \& Jordan, A. 2013. The Importance of Culture: Should Culture be Translated? International Journal of Applied Linguistics \& English Literature, 2 (2), 96100.

Anonym. 2018. Donal Bebek. $1906^{\text {th }}$ Edition. Jakarta: PT PenerbitanSaranaBobo under the licence from The Walt Disney Co.

Anonym. 2018. Donal Bebek. 1907 ${ }^{\text {th }}$ Edition. Jakarta: PT PenerbitanSaranaBobo under the licence from The Walt Disney Co.

Collins, Suzanne. 2008. The Hunger Games. United States: Scholastic Press.

Collins, Suzanne. 2009. Catching Fire. United States: Scholastic Press.

Collins, Suzanne. 2009. The Hunger Games. Translated by HetihRusli. Jakarta: GramediaPustakaUtama.

Collins, Suzanne. 2010. Catching Fire. Translated by HetihRusli. Jakarta: GramediaPustakaUtama.

Collins, Suzanne. 2010. Mockingjay. United States: Scholastic Press.

Collins, Suzanne. 2012. Mockingjay. Translated by HetihRusli. Jakarta: GramediaPustakaUtama.

Denham, K. \&Lobeck, A.. 2013. Linguistics for Everyone: An Introduction. $2^{\text {nd }}$ Ed. USA: Wadsworth, Cengage Learning.

Heriyati, 2010. Kamus Gaul BahasaInggris. Yogyakarta, Indonesia: Mizan Media Utama.

Jaleniauskienè, E. \& Čičelytè, V. 2009. The Strategies for Translating Proper Names in Children's Literature. Studies about Languages, 15, 31-42.

Muhartoyo\&Wijaya, B.S..2014. The Use of English Slang Words in Informal Communication among $8^{\text {th }}$ Semester Students of English Department in Binus University. Humaniora, 5 (1), 197-209

Newmark, P.. 1988. A Textbook of Translation. Pearson Education Limited.

Pour, B.S. 2009. How to Translate Personal Names. Translation Journal, 13(4), 1-13.

Simanjuntak, H.L..2014. The Translation of Articles "A/An"and "The" Into Indonesian. UG Jurnal, 8 (2), 9 -1 2

Zarei, R. \&Norouzi, S..2014. Proper Nouns in Translation: Should They Be Translated? International Journal of Applied Linguistics \& English Literature, 3 (6), 152-161. 
Susanti, Kadarisman, Possible Techniques for Translating | 67

Zhou, Y. \& Fan, Y.2013. A Sociolinguistic Study of American Slang. Theory and Practice in Language Studies, 3 (12), 2209-2213. 